Ilmu Pertanian (Agricultural Science)

Vol. 4 No. 1 April, 2019: 46-51

Available online at http://journal.ugm.ac.id/jip

DOI: doi.org/10.22146/ipas.40693

\title{
CIE $L * a * b *$ Color Space Based Vegetation Indices Derived from Unmanned Aerial Vehicle Captured Images for Chlorophyll and Nitrogen Content Estimation of Tea (Camellia sinensis L. Kuntze) Leaves
}

\author{
Wahono*, Didik Indradewa, Bambang Hendro Sunarminto, \\ Eko Haryono and Djoko Prajitno \\ Department of Agronomy, Faculty of Agriculture, Universitas Gadjah Mada \\ Jln. Flora No. 1, Bulaksumur, Sleman, Yogyakarta 55281, Indonesia \\ *Corresponding author: j_wahono@yahoo.com
}

Received: 09 $9^{\text {th }}$ November 2018; Revised: 09 $9^{\text {th }}$ April 2019; Accepted: $10^{\text {th }}$ April 2019

\begin{abstract}
A lot of digital image techniques to assess the crop agronomic character have been developed, most of which are based on non-visible light equipped cameras, such as infrared wavelengths. This research aimed to examine the use of commercial digital camera with sensor range in visible light spectrum using CIE L*a*b* color space to estimate chlorophyll and nitrogen content of tea leaf. Data were collected from an experiment of nitrogen dosage levels on 3 years after pruning of tea crops. The result showed that Lb* Difference Simple Index (LI), a*b* Difference Simple Index (AI), and $a^{*}$ Vegetation Index (VIA) can be used to estimate tea leaf chlorophyll and nitrogen content. The corrrelation between VIA and tea leaf nitrogen content was defined on quadratic equation $\mathrm{y}=1.8382 \mathrm{x}^{2}-0.3099 \mathrm{x}+$ 3.0658 with determinant coefficient $\mathrm{R}^{2}=0.71$.
\end{abstract}

Keywords: Nitrogen fertilizing, unmanned aerial vehicle, visible light spectrum

\section{INTRODUCTION}

Nitrogen is an important element which composes chlorophyll pigment making it highly correlated with leaf chlorophyll content (Lamb et al., 2002). The leaf nitrogen content is a dominant factor affecting tea crop growth, productivity, and yield quality (Owuor et al., 2010; Sarwar et al., 2011; Hamid et $a l ., 2014)$. The dominant role of nitrogen content on crop production affects productivity and improving economic efficiency.

The amount of chlorophyll is responsible to leaf's reflectance; the greener leaf seen by human eyes indicates more chlorophyll content of the leaf. The content of leaf chlorophyll is sensitive to environmental stresses that disrupt plant metabolism (Knipling 1970; Woolley 1971). As the absorption of visible light radiation energy is highly determined by the presence of leaf pigments (Buschmann et al., 2012), the chlorophyll reflectance which is the dominant leaf pigment can be used as an indicator of plant health. The availability of nitrogen for plants will be reflected in the amount of chlorophyll so that the chlorophyll reflectance can be used as an indicator of plant nitrogen status.

There were efforts to obtain a mathematical relationship between the visible light reflectance and leaf chlorophyll content in the form of vegetation indices (Anderson et al. 2016; Xue \& Su 2017). In general, vegetation indices derived from RGB color space has the disadvantage comes from digital values inconsistencies of images with different recording times and sensors. CIE L*a*b* color space is an independent mathematical model device representing colors that humans can perceive $\mathrm{L}^{*}$ elements accommodate lightness (Bora et al., 2015). This character has the potential to be applied to assess leaf chlorophyll content from images with different recordings. $\mathrm{L}^{*} \mathrm{a} \mathrm{b}^{*}$ color space has been used previously to segment vegetation in an effort to extract wind erosion barriers with CIR (Color Infra Red) imagery (Zhang et al., 2006). They use infrared color imagery as a component in the RGB image, namely infrared replacing the value of red, red replacing 
green, and green replacing blue. It was found that the value of component $b *$ of CIE $\mathrm{L}^{*} \mathrm{a} * \mathrm{~b}$ color space transformed from $510 \mathrm{~nm}$ and $516 \mathrm{~nm}$ wavelength reflectances can be used as an estimating parameter of nitrogen nutrient status of broccoli crops (Graeff et al., 2008). Instead of its different objectives of application, the transformation of CIE L*a*b* color space from RGB digital images provided better results in sorting vegetation objects from non-vegetation objects (Li et al., 2012).

Recently the use of micro unmanned aerial vehicles (UAV) to collect a vegetation surface images becomes popular because of its advantages comparing to other platforms such as satellite imagery (Pearse et al., 2017). The most important advantage of UAV use in agriculture is the capability of fastly large coverage of high-resolution images of plant surfaces in a high spatial and temporal resolution. Those advantages open possibilities to develop precise agronomic prescription for better crop production. The aim of this research was to examine vegetation indices derived from CIE L*a*b* color space transformed from RGB digital images to assess nitrogen and chlorophyll content of tea leaves.

\section{MATERIALS AND METHODS}

\section{Site and experimental design}

The research was carried out at Wonosari Tea Plantation (PTPN XII), Lawang, Malang Regency, East Java, Indonesia with a geographical position of $-07^{\circ} 49^{\prime} 17.6^{\prime \prime}$ (latitude) 112 $38^{\prime} 36^{\prime \prime}$ (longitude). The altitude of the plantation is $905-1050$ meters above sea level. The soil type of field is dominated by Andosol. The daily air temperature ranges from $15^{\circ}$ to $28^{\circ} \mathrm{C}$, and the anual rainfall is about $3000 \mathrm{~mm}$. The experiment was conducted from February to May 2015.

Data were collected from an $\mathrm{N}$-rates experiment comprised $18 \times 27$ meters plots selected from homogeneous 3 years old after pruning productive crop and arranged in a Completely Randomized Design. The rates of nitrogen treatment was determined based on the percentage of the highest dose applied by the company at the trial location, which was: $0 \%$ (control), 25\%, 50\%, 75\%, 100\%, and $125 \%$ with 3 replications. The fertilizer dose was $350\left(\mathrm{~kg} \cdot \mathrm{ha}^{-1}\right)$. year $^{-1}$ (Effendi et al., 2011). Referring to the practice of fertilization at the research site, fertilization was carried out 4 times a year. Furthermore, each level was divided by the plant population per hectare to determine the dose of fertilizer that would be applied to each plant in the experimental plot. The application of fertilizer was carried out 2 weeks before the first observation, after picking time by burying it in 4 separate points, each of which was $60 \mathrm{~cm}$ apart from the stem.

\section{Sampling and observations}

Observations were made 32 days after treatment (DAT) which was on March 19, 2015. On each trial plot, samples of plant shoots were marked with a marker frame that could be seen from a camera mounted on an unmanned aircraft (3DR Iris multirotor). The sample frame was shaped with a + sign with a hole in the middle. The size of the hole was $25 \times 25 \mathrm{~cm}$. The shoot leaf sample was selected inside the marker frame. Aerial photo recording was carried out using Canon S100 (Canon Inc.) camera mounted on an unmanned aircraft. The aircraft was programmed to fly across the path above the experimental field at an altitude of 75 meters above ground level. The flight path programming was done using Mission Planner software. Spectral data were taken from marked pixels from each sample. Aerial photo recording was done between 8:00 and 10:00 am.

Immediately after the image recording, sample of leaves were picked and taken to the laboratory in a styrofoam box filled with ice cubes for analysis. Five fresh leaves from each observation point were extracted with $96 \%$ of ethanol (v/v) and the absorbance was measured in channels of 649 and $665 \mathrm{~nm}$ using a spectrophotometer. Chlorophyll content was calculated based on the Arnon method.

Determination of nitrogen concentration was carried out first by drying the leaves of the sample at $105^{\circ} \mathrm{C}$ for 30 minutes so that the enzyme activity of polyphenol oxidase stopped quickly. Subsequent drying was carried out at $70^{\circ} \mathrm{C}$ until a stable dry weight was achieved. The dried leaves were crushed and the $\mathrm{N}$ content was determined using Kjehldahl method. Measurements were made 3 times from every sample which then be averaged as a value of 1 sample observation.

\section{Data Processing and statistical analysis}

The reading of digital values on the red, green, blue (RGB) channel of aerial photography was done using Fiji Image Processing software. The digital data were extracted from the leaves of previously marked samples that were the same as those used for destructive analysis in the laboratory. The digital RGB value data were then converted to the XYZ color space and finally $\mathrm{L}^{*} \mathrm{a} * \mathrm{~b} *$ used the method which was the same as Zhang et al. (2006). There 
Table 1. Vegetation indices derived from $\mathrm{L}^{*} \mathrm{a} * \mathrm{~b} *$ images

\begin{tabular}{lll}
\hline Abbreviation & Index & Equation \\
\hline LI & Lb* Difference Simple Index & $\mathrm{L}^{*}-\mathrm{b}^{*}$ \\
AI & $\mathrm{a}^{*} \mathrm{~b}^{*}$ Difference Simple Index & $\mathrm{b}^{*}-\mathrm{a}^{*}$ \\
AL & $\mathrm{a}^{*} \mathrm{~L}^{*}$ Simple Ratio & $\mathrm{a}^{*} / \mathrm{L}^{*}$ \\
AB & $\mathrm{a}^{*} \mathrm{~b}^{*}$ Simple Ratio & $\mathrm{a}^{*} / \mathrm{b}^{*}$ \\
NDLBI & Normalized Difference $\mathrm{L}^{*} \mathrm{~b}^{*}$ Index & $\left(\mathrm{L}^{*}-\mathrm{b}^{*}\right) /\left(\mathrm{L}^{*}+\mathrm{b}^{*}\right)$ \\
NDALI & Normalized Difference $\mathrm{a}^{*} \mathrm{~L}^{*}$ Index & $\left(\mathrm{a}^{*}-\mathrm{L}^{*}\right) /\left(\mathrm{a}^{*}+\mathrm{L}^{*}\right)$ \\
NDABI & Normalized Difference $\mathrm{a}^{*} \mathrm{~b}^{*}$ Index & $\left(\mathrm{a}^{*}-\mathrm{b}^{*}\right) /\left(\mathrm{a}^{*}+\mathrm{b}^{*}\right)$ \\
VIA & $\mathrm{a}^{*}$ Vegetation Index & $\mathrm{a}^{*} / 120$ \\
\hline
\end{tabular}

Remarks: : $\mathrm{L}^{*}, \mathrm{a}^{*}, \mathrm{~b}^{*}=$ digital value of channel $\mathrm{L}^{*}, \mathrm{a}^{*}$, and $\mathrm{b}^{*}$ respectively

were 8 vegetation indices calculated by combining the values of the $L^{*}, a^{*}$, and $b^{*}$ channels (Table 1 ). The a* Vegetation Index (VIA) was similar to Zhang's a index (Zhang et al., 2006) but different in the value input. Instead of using CIR data as in Zhang's index, VIA was derived from RGB data. The other indices tested in this research were developed by applying simple arithmetic to the $\mathrm{L}^{*}, \mathrm{a}^{*}$, and $\mathrm{b}^{*}$ values. Statistical analysis of both the vegetation index and destructive $\mathrm{N}$ measurements was carried out using MS Excel 2013 software.

\section{RESULTS AND DISCUSSION}

Effect of $\mathbf{N}$ fertilizer doses on nitrogen content, leaf chlorophyll, and index value

Anova test showed that dose of $\mathrm{N}$ fertilizer had a significant effect $(\mathrm{P}<0.01)$ on $\mathrm{N}$ content and chlorophyll content as presented in Table 2. As showed in Table 2 , the highest level of $\mathrm{N}$ leaf tea was achieved in the highest treatment dose of fertilizer (109.4 kg N.ha $\left.{ }^{-1}\right)$ but not significantly different from the treatment of $43.8 \mathrm{~kg} \mathrm{~N} \mathrm{ha}^{-1}$. The similar result was found in the effect of doses of $\mathrm{N}$ fertilizer on tea leaf chlorophyll content. Those results was conjectured to be related to the mobile property of $\mathrm{N}$ elements in plants; in case of $\mathrm{N}$ deficiency there will be $\mathrm{N}$ translocation from older leaves to shoots. The results of this test indicate that the experimental data for $\mathrm{N}$ doses sufficiently provide the range of $\mathrm{N}$ content and chlorophyll of leaves needed in the experiment in compiling the vegetation indices.

Descriptive statistical information on $\mathrm{L}^{*}, \mathrm{a}^{*}$, and $b^{*}$ channel values from aerial photographs in the experimental plot is presented in Table 3 . The average of the $\mathrm{L}^{*}$ channel value was 32.99 with a standard deviation of 5.30. These values showed that the population of the $\mathrm{L}^{*}$ value was in the positive zone. It implied an indication of the lightness of the images. A negative value would give a blackish tone; the smaller the value of $L^{*}$, the darker the image would be due to lack of light. The average of a* channel was -39.0 indicating the dominance of green while positive value of a* indicated the dominance of yellow. Only one sample was found to have a $*$ positive value (0.83) in the treatment dose of $\mathrm{N} 0 \mathrm{~kg} \cdot \mathrm{ha}^{-1}$, however because the other two samples were negative, the average of $\mathrm{a}^{*}$ for the treatment dose of $\mathrm{N} 0 \mathrm{~kg}$. $\mathrm{ha}^{-1}$ remained negative.

Here are the results of observations on the effect of doses of $\mathrm{N}$ fertilizer on the value of the examined vegetation indices (Table 3). The LI, AI, NDLBI,

Table 2. Effect of $\mathrm{N}$ fertilizer doses on $\mathrm{N}$ content and chlorophyll content of tea shoots

\begin{tabular}{lcc}
\hline N Dosage $\left(\mathrm{kg} \mathrm{N}^{-} \mathrm{ha}^{-1}\right)$ & N content $(\%)$ & Chlorophyll $\left(\mathrm{mg}^{\mathrm{m}} \mathrm{mg}^{-1}\right)$ \\
\hline 0.0 & $3.06 \mathrm{~b}$ & $1.01 \mathrm{~b}$ \\
21.9 & $3.10 \mathrm{~b}$ & $1.05 \mathrm{~b}$ \\
43.8 & $3.16 \mathrm{ab}$ & $1.04 \mathrm{ab}$ \\
65.6 & $3.13 \mathrm{ab}$ & $1.07 \mathrm{ab}$ \\
87.5 & $3.24 \mathrm{a}$ & $1.13 \mathrm{a}$ \\
109.4 & $3.29 \mathrm{a}$ & $1.14 \mathrm{a}$ \\
\hline CV $(\%)$ & 4.86 & 8.32 \\
\hline
\end{tabular}

Remarks: $\mathrm{CV}=$ Coefficient of Variance 
and NDLAI indices had a range of positive values while the $\mathrm{AL}, \mathrm{AB}$ and VIA indices were negative, and the NDABI index had a range of negative to positive values. The results of ANOVA analysis showed that the dose of $\mathrm{N}$ fertilizer significantly affected $(\mathrm{P}<0.05)$ the LI, AI, and VIA indices values. AI was a vegetation index calculated from a simple arithmetic operation by subtracting the channel value $b^{*}$ from the value of channel $a^{*}$ where the channel $a^{*}$ held the green-red color while $b^{*}$ held the blue-yellow color. Positive AI values were generally formed by negative $a^{*}$ values (green) while $b^{*}$ values were positive (yellow) in all observations (Table 2). The VIA index was found to be negative because the channel of a* value was dominated by negative values (green) as presented in Table 2.

Table 3. Descriptive statistics of digital value of $\mathrm{L}^{*}, \mathrm{a}^{*}$, and $\mathrm{b}^{*}$ channels

\begin{tabular}{lccc}
\hline & $\mathrm{L}^{*}$ & $\mathrm{a}^{*}$ & $\mathrm{~b}^{*}$ \\
\hline Mean & 32.99 & -17.84 & 21.03 \\
Median & 32.38 & -17.45 & 21.20 \\
Variance & 28.08 & 94.96 & 82.20 \\
SD & 5.30 & 9.74 & 9.07 \\
Minimum & 24.17 & -39.00 & 7.99 \\
Maximum & 43.49 & 0.83 & 40.63 \\
Range & 19.32 & 39.83 & 32.64 \\
\hline
\end{tabular}

Table 4. Effect of $\mathrm{N}$ fertilizer doses on vegetation index values

\begin{tabular}{lcccccccc}
\hline $\begin{array}{l}\mathrm{N} \mathrm{dose} \\
\left(\mathrm{kg} \mathrm{N} \mathrm{ha}^{-1}\right)\end{array}$ & LI & AI & AL & AB & NDLBI & NDLAI & NDABI & VIA \\
\hline 0.0 & $38.2 \mathrm{c}$ & $26.5 \mathrm{c}$ & $-0.32 \mathrm{a}$ & $-0.66 \mathrm{a}$ & $0.26 \mathrm{a}$ & $2.5 \mathrm{a}$ & $-0.6 \mathrm{a}$ & $-0.07 \mathrm{a}$ \\
21.9 & $38.5 \mathrm{c}$ & $25.7 \mathrm{c}$ & $-0.35 \mathrm{a}$ & $-0.70 \mathrm{a}$ & $0.31 \mathrm{a}$ & $2.2 \mathrm{a}$ & $-179.2 \mathrm{a}$ & $-0.09 \mathrm{a}$ \\
43.8 & $40.1 \mathrm{c}$ & $31.0 \mathrm{bc}$ & $-0.48 \mathrm{a}$ & $-0.95 \mathrm{a}$ & $0.34 \mathrm{a}$ & $3.2 \mathrm{a}$ & $-46.1 \mathrm{a}$ & $-0.13 \mathrm{a}$ \\
65.6 & $50.9 \mathrm{~b}$ & $41.1 \mathrm{~b}$ & $-0.53 \mathrm{a}$ & $-0.76 \mathrm{a}$ & $0.17 \mathrm{a}$ & $3.4 \mathrm{a}$ & $-12.0 \mathrm{a}$ & $-0.15 \mathrm{ab}$ \\
87.5 & $59.6 \mathrm{ab}$ & $46.9 \mathrm{~b}$ & $-0.68 \mathrm{a}$ & $-1.26 \mathrm{a}$ & $0.28 \mathrm{a}$ & $7.4 \mathrm{a}$ & $-0.1 \mathrm{a}$ & $-0.20 \mathrm{~b}$ \\
109.4 & $71.4 \mathrm{a}$ & $62.0 \mathrm{a}$ & $-0.77 \mathrm{a}$ & $-1.00 \mathrm{a}$ & $0.13 \mathrm{a}$ & $10.8 \mathrm{a}$ & $21.1 \mathrm{a}$ & $-0.26 \mathrm{~b}$ \\
& $*$ & $*$ & $\mathrm{~ns}$ & $\mathrm{~ns}$ & $\mathrm{~ns}$ & $\mathrm{~ns}$ & $\mathrm{~ns}$ & $*$ \\
\hline
\end{tabular}

Remarks: Numbers followed by different letters in the same column indicate significant differences in the Tukey HSD test; * $=$ significant $(\mathrm{P}<0.05)$; $\mathrm{ns}=$ not significant.

Abbreviations: $\mathrm{LI}=\mathrm{Lb} *$ Difference Simple Index); $\mathrm{AI}=\mathrm{a} * \mathrm{~b} *$ Difference Simple Index; $\mathrm{AL}=\mathrm{a} * \mathrm{~L} *$ Simple Ratio; $\mathrm{AB}=\mathrm{a} * \mathrm{~b} *$ Simple Ratio; NDLBI $=$ Normalized Difference $\mathrm{L}^{*} \mathrm{~b} *$ Index; NDALI $=$ Normalized Difference $\mathrm{a}^{*} \mathrm{~L} *$ Index; NDABI $=$ Normalized Difference $\mathrm{a}^{*} \mathrm{~b}$ Index; VIA $=\mathrm{a}^{*}$ Vegetation Index

Table 5. Correlation between vegetation index and nitrogen content and tea shoots chlorophyll content

\begin{tabular}{ccc}
\hline Index & $\mathrm{N}$ & Chlorophll \\
\hline LI & $0.75^{*}$ & $0.90^{*}$ \\
AI & $0.80^{*}$ & $0.90^{*}$ \\
AL & -0.64 & -0.74 \\
AB & -0.33 & -0.39 \\
NDLBI & 0.37 & 0.28 \\
NDLAI & 0.69 & 0.68 \\
NDABI & -0.32 & -0.36 \\
VIA & $-0.82^{*}$ & $-0.90^{*}$ \\
\hline
\end{tabular}

Remarks: * $\mathrm{P}<0,0$.

Abbreviations: $\mathrm{LI}=\mathrm{Lb} *$ Difference Simple Index); $\mathrm{AI}=\mathrm{a} * \mathrm{~b} *$ Difference Simple Index; $\mathrm{AL}$ $=a * L *$ Simple Ratio; $A B=a * b *$ Simple Ratio; NDLBI $=$ Normalized Difference $\mathrm{L} * \mathrm{~b} *$ Index; NDALI $=$ Normalized Difference $a * \mathrm{~L}^{*}$ Index; NDABI $=$ Normalized Difference $\mathrm{a}^{*} \mathrm{~b}$ Index; VIA $=\mathrm{a}^{*}$ Vegetation Index 


\section{Regression between vegetation index with nitrogen and chlorophyll content}

Pearson regression test showed that the LI index and $\mathrm{AI}$ were in significantly positive regression $(\mathrm{r}=$ $0.90 ; \mathrm{P}<0.01)$ with tea leaf chlorophyll content (Table 5). Table 5 also showed that the VIA index was in significantly negative regression $(r=0.90 ; \mathrm{P}$ $<0.01)$ on leaf chlorophyll content. These results indicated that an increase in LI and AI index values will be followed by a increase in leaf chlorophyll content and vice versa, while an increase in VIA value will be followed by a decrease in leaf chlorophyll content. There was no significant regression between $\mathrm{AL}, \mathrm{AB}, \mathrm{NDLBI}, \mathrm{NDLAI}$, and NDABI indices with tea leaf chlorophyll content. These results were consistent with the effect of doses of $\mathrm{N}$ fertilizer in the index value as presented in Table 4. Regression coefficients of LI, AI, and VIA indices showed that the three indices were equally good at explaining changes in chlorophyll content in shoots of tea plants. Although not much at odds compared to the AI index, the VIA index provided the highest regression coefficient value, which was -0.82 ( $\mathrm{P}$ $<0.01$ ) for leaf nitrogen content (Table 5). This is an indication that the VIA index can explain changes in the value of leaf nitrogen content better than other indices. Thus VIA is the best vegetation index for estimating chlorophyll content and/or leaf nitrogen content among other indices tested.

The results of the regression analysis of the VIA index with leaf chlorophyll content and leaf nitrogen content are shown in graphical form in Figure 1. The regression lines suitable for modeling the regression between VIA values and shoots' chlorophyll content were shown by linear equation of $y=-0.6655 x+$ $0.9682\left(\mathrm{R}^{2}=0.81\right)$. (Figure 1A). The regression between VIA values and nitrogen content of shoots follows a quadratic pattern with the equation of $\mathrm{y}=$ $1.8382 \times 2-0.3099 x+3.0658\left(\mathrm{R}^{2}=0.71\right)$ (Figure 1B). Both of these equations indicated that a decrease in VIA value would be followed by an increase in

(A)

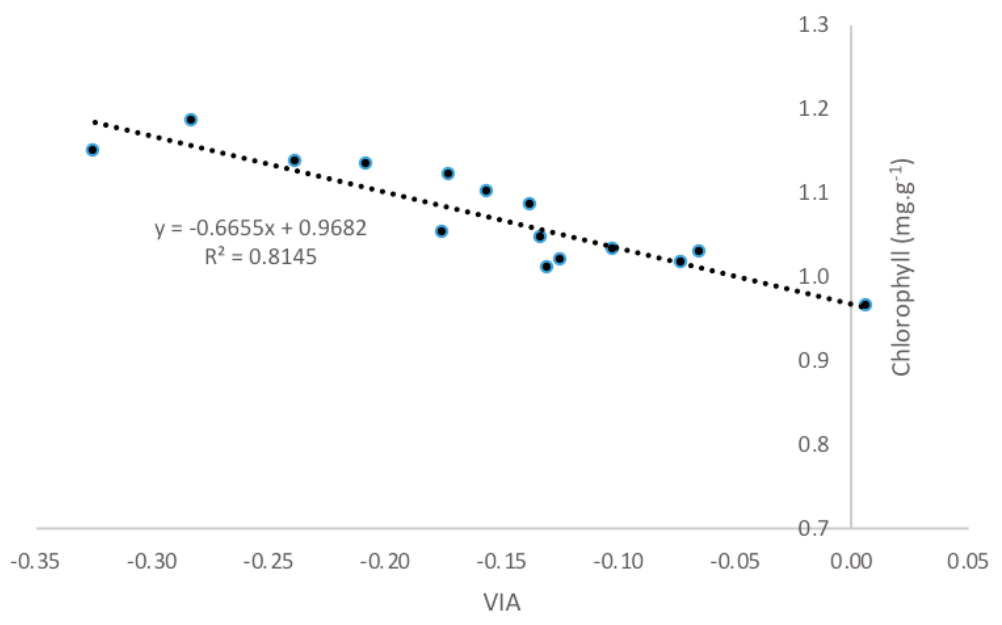

(B)

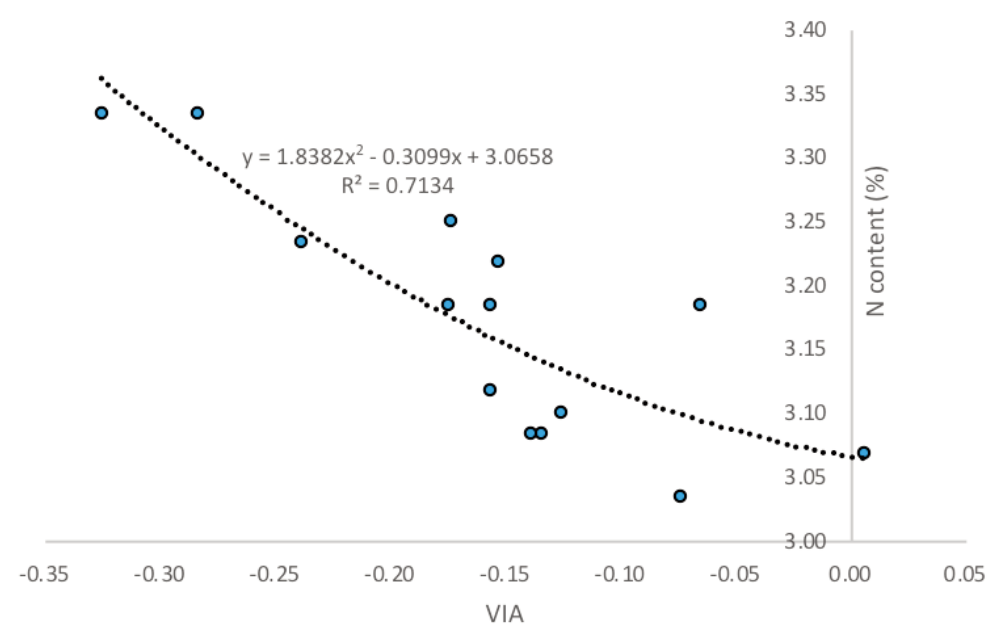

Figure 1. Regression between the VIA and content of chlorophyll (A) and content of $\mathrm{N}$ of tea shoots (B) 
chlorophyll content or nitrogen content of shoots of tea plants. These equations can be used to quickly assess the chlorophyll content and or $\mathrm{N}$ leaf tea using recording from unmanned aircraft.

\section{CONCLUSIONS}

The Lb* Difference Simple Index (LI), $\mathrm{a}^{*} \mathrm{~b}^{*}$ Difference Simple Index (AI), and $\mathrm{a}^{*}$ Vegetation Index (VIA) values were affected by chlorophyll and leaf nitrogen content. The $a^{*}$ Vegetation Index was a reliable estimator and can be used to estimate leaf chlorophyll and $\mathrm{N}$ content using digital image data from the visible light range acquired from unmanned aircraft. The results of this research indicating the vegetation index derived from transformation of visible light range digital images into CIE $\mathrm{L}^{*} \mathrm{a} * \mathrm{~b}^{*}$ color space has potential to improve the efficiency of $\mathrm{N}$ fertilization on tea plantations.

\section{ACKNOWLEDGEMENT}

Sincere thanks to Wonosari Tea Plantation PTPN XII for facilitating us to conduct experiment on their field.

\section{REFERENCES}

Anderson, H.B., L. Nilsen., H. Tommervik., S.R. Karlsen., S. Nagai and E.J. Cooper. 2016. Using ordinary digital cameras in place of near-infrared sensors to derive vegetation indices for phenology studies of High Arctic vegetation. Remote Sensing., 8:10.

Bora, D.J., A.K. Gupta and F.A. Khan. 2015. Comparing the performance of $\mathrm{L}^{*} \mathrm{~A} * \mathrm{~B}^{*}$ and $\mathrm{HSV}$ color spaces with respect to color image segmentation. International Journal of Emerging Technology and Advanced Engineering., 5:192-203.

Buschmann, C., S. Lenk and H.K. Lichtenthaler. 2012. Reflectance spectra and images of green leaves with different tissue structure and chlorophyll content. Israel Journal of Plant Sciences., 60:49-64.

Effendi, D.S., M. Syakir., M. Yusron and Wiratno, 2011. Budidaya dan pasca panen teh. Bogor: Pusat Penelitian dan Pengembangan Perkebunan.

Graeff, S., J. Pfenning., W. Claupein and H. Liebig., 2008. Evaluation of image analysis to determine the $\mathrm{n}$-fertilizer demand of broccoli plants (Brassica oleracea convar. botrytis var. italica). Advances in Optical Technologies., 1-8.
Hamid, F.S., T. Ahmad., A. Waheed., N. Ahmad and S. Aslam. 2014. Effect of different levels of nitrogen on the chemical composition of tea (C. Sinensis L.) grown at higher altitude. Journal of Materials and Environmental Science., 5:72-80.

Knipling, E.B. 1970. Physical and physiological basis for the reflectance of visible and near infrared radiation from vegetation. Remote Sensing of Environment., 1:155-159.

Lamb, D.W., M. Steyn-Ross., P. Schaare., M.M. Hanna., W. Silvester and A. Steyn-Ross. 2002. Estimating leaf nitrogen concentration in ryegrass ( Lolium spp.) pasture using the chlorophyll red-edge: Theoretical modelling and experimental observations. International Journal of Remote Sensing., 23:3619-3648.

Li, C., F. Li., Y. Liu., X. Li., P. Liu and B. Xiao. 2012. Study on the feasibility of RGB substitute CIR for automatic removal vegetation occlusion based on ground close-range building images. ISPRS - International Archives of the Photogrammetry, Remote Sensing and Spatial Information Sciences., 227-230.

Owuor, O.P., D.M. Kamau and E.O. Jondiko. 2010. The influence of geographical area of production and nitrogenous fertiliser on yields and quality parameters of clonal tea. Journal of Food, Agriculture \& Environment., 8:682-690.

Pearse, G.D., J. P. Dash., H.S. Dungey., M.S. Watt and M. Heaphy. 2017. Assessing very high resolution UAV imagery for monitoring forest health during a simulated disease outbreak. ISPRS Journal of Photogrammetry and Remote Sensing., 131:1-14.

Sarwar, S., F. Ahmad and F.S. Hamid. 2011. Effect of nitrogenous fertilizer on the growth and yield of tea (Camellia sinensis L.) pruned in curved vs flat shape. J. Agric. Res., 49:477482.

Woolley, J.T. 1971. Reflectance and transmittance of light by leaves. Plant physiology, 47:65662.

Xue, J. and B. Su. 2017. Significant remote sensing vegetation indices: A review of developments and applications. Journal of sensors., 17

Zhang, Y., C. Heipke., M. Butenuth and X. Hu. 2006. Automatic extraction of wind erosion obstacles by integration of GIS data, DSM and stereo images. International Journal of Remote Sensing, 27:1677-1690. 